\title{
THE DEVELOPMENT OF TEACHING MATERIALS WITH PROBLEM BASED LEARNING ON THE MATHEMATICAL STATISTICS SUBJECT TO IMPROVE STUDENTS' CRITICAL THINKING ABILITY
}

\author{
$\operatorname{Irvan}^{1+}$ \\ Rahmad \\ Mushlihuddin ${ }^{2}$ \\ Universitas Muhammadiyah of Sumatera Utara \\ 'Email:irvan@umsu.ac.id \\ EEmail:_rahmatmushlihuddin@umsu.ac.id
}

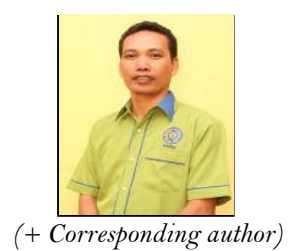

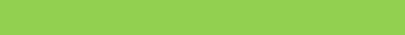

Article History

Received: 4

Revised:

Accepted:

Published:

\section{Keywords}

Teaching materials, LKM, Problem

Based Learning, Mathematical

Statistics

\begin{abstract}
The existence of teaching materials has an important role in the learning process. One way to improve the quality of learning is by providing teaching materials (LKM) based on needs. Teaching materials used in this study are the student worksheets based on problems in mathematics statistics courses. The purpose of this study is to develop, test and determine the effectiveness of problem-based teaching materials (LKM). This study applies qualitative and quantitative descriptive data analysis and percentage techniques. The result of this study obtained: Problem-based teaching materials (LKM) that use critical thinking skills indicators; the feasibility of problem-based teaching materials (LKM) according to the lecturers or friends, with an average of $88.69 \%$ (good), while according to the students it obtained an average of $81.26 \%$ (good). Teaching Materials (LKM) for Mathematical Statistics based on effective problems improve critical thinking skills with a gain of 14.17 and $\mathrm{N}$-gain 0.38 in the medium category.
\end{abstract}

\section{INTRODUCTION}

Teaching experience is changing faster and faster, it can be seen in the curriculum of Higher Education SN. In the curriculum, it requires learning achievement from each subject delivered by the lecturer. So that the lecturer is required to carry out innovations in class learning. Therefore, learning no longer centers on lecturers or instructors. At this time the learning carried out in the Mathematics Education study program has applied student-centered learning, in which the students have been involved in finding out information related to the subjects, especially by presenting the tasks given by the lecturer. One factor that can support the student independence in learning is the availability of adequate learning resources. Textbooks are the sources of learning that can be used by students to find information about the material being studied. Although textbooks can be found easily by students, their existence is not fully able to support the students' understanding towards the materials they learn. Therefore, mathematics statistics is compulsory subjects for students of mathematics education study program which has 3 credits. It is an applied subject which is important for the students. It applies many concepts related to other subjects such as differential calculus, internal calculus and Probability.

Competencies that must be achieved after learning mathematics statistics are that students are able to apply the concepts of probability; distinguish discrete random variables, continuous random variables, and exponential family distributions; differentiate the properties of expectation values, conditional expectations, and the function of the moment generator; differentiate the properties of expectation values, conditional expectations, and moment generating functions, and explain the transformation of random variables using distribution function techniques, transformation methods, convolution formulas, and moment generating functions. The achievement of these competencies is supported by many factors. One of them is the use of teaching materials. Observations and interviews were conducted on lecturers and students of the Mathematics Education Study Program at FKIP UMSU, especially in lecturing mathematical statistics, it obtained information that generally, the students did not have adequate teaching materials for a conducive learning process, especially printed teaching materials.

Provided teaching materials of mathematics statistics are so few that the students feel very difficult to obtain. While the learning resources provided by the lecturers are textbooks. Materials on mathematics statistics contained in this textbook is not structured as the Higher Education SN curriculum. All required materials are provided in this textbook. However, not all of them are taught in this course. This irregularity causes the continuity of the material to be disrupted. The technique of presenting material in textbooks is not able to actively involve the students in making discoveries to build concepts on the materials they learn. Lack of the students' involvement in building concept understanding resulted in that students will easily forget the material. In addition, students also have 
IJEMS: Indonesian Journal of Education and Mathematical Science

2020 Vol. $x$, No. $1, p p$.

$\operatorname{ISSN}(e): 2715-985 x$

DOI: https://doi.org/10.30596/ijems.v2i1.5626

(C)2020IJEMS@UMSU.All RightsReserved.

difficulties to transfer their knowledge in various contexts. To improve the ability to think critically in mathematics education students, alternative problem solving is chosen by developing a teaching material. Teaching material is one of the learning resources used to facilitate the distribution of messages from lecturers to students. The instructional material to be developed is printed materials in the form of Student Worksheets (LKM). Development of teaching material is expected to overcome the problem supporting the learning process so that it is easily understood by students (Oktaviani, D.N. and Rokhman, M.S. 2014). MFIs can be interpreted as sheets used by students as guidelines in the learning process, as well as containing assignments done by students in the form of questions and activities without having to be guided by the lecturer so that students can do it themselves (Irvan, et.al. 2015). The use of Student Worksheets can encourage students to: (a) Have meaningful knowledge; (b) Enjoy the subjects and learning methods they use; (c) be motivated to learn and solve problems and projects in Student Worksheets independently, active during lecturing (Mairing, J.P. and Dadang, L. 2013).

Lecturing on mathematics statistics at the mathematics education program FKIP UMSU has applied LKM by using the Dick and Carey Design model, but these it is still not empowering students' critical thinking skills because they only do activities according to the instructions without giving students the opportunity to find their own concepts in lecturing or in solving the given. Through lecturing on mathematics statistics, the students are expected to be able to think critically to find solutions to real life problems. LKM that is able to encourage students to think critically through problem solving in the problems that exist in the material of mathematics statistics and in real life need to be developed to solve these problems. Problem Based Learning is a pattern or a plan that is used as a guide to plan learning by raising an authentic problem that occurs in real life that must be resolved. The syntax or steps of the Problem Based Learning model started by orienting the problem, organizing to research, assisting in investigation, presenting the work and analyzing and evaluating the process of overcoming the problem. PBL provides opportunities for students to explore, collect and analyze data completely to solve the problems. The goal to be achieved is the ability to think critically, analytically, systematically, and logically to find alternative solutions to the problem through exploration and empirically in order to foster a scientific attitude (Tanjung, D.F., et.al. 2020; Mushlihuddin R. et.al. 2018). Through learning PBL models, it is expected that the students can learn to think and solve their own problems, because the role of lecturers only functions as mentors and facilitators.

Problem-based learning is the interaction between stimulus and response, a relationship between two directions of learning and the environment (Mushlihuddin R. et.al. 2018; Mushlihuddin R. dan Irvan, 2017). The environment provides input to students in the form of assistance and problems, while the nervous system of the brain functions to interpret the aid effectively so that the problem can be investigated, assessed, analyzed, and searched properly. Next (Arends, L.R. 2008) it states that PBL helps students develop their skills of thinking and problem solving, learn the roles of adult and become independent students. From this statement it can be concluded that learning something the learning material is always demanded activities that function to solve the problem. This is related to the character of problem-based learning, that is students are required to study independently and are always associated with the real world. Some important things in problem-based learning (Arends, L.R. 2008) are:

1. Students are required to make a written report called an artifact.

2. Students solve the problems "cooperatively" or work together in small groups in solving the given problems.

3. Applying the performance assessments to solve the problems and to measure the group work.

4. Lecturers must be able to use valid and reliable measurement techniques.

5. Students present the results / solutions of the investigated problems.

6. Lecturers provide problems and students investigate and find the solution themselves.

7. Student learning environment is characterized by openness, student involvement, atmosphere of intellectual freedom.

The above ideas can create critical thinking skills for the students in the teaching and learning process conducted in the classroom. Lecturers only provide issues related to the materials being taught while students will find solutions to the problems. Critical thinking skills of students greatly influence the quality of understanding concepts. One indicator of students' intellectual abilities is they are able to understand the concepts (Sudjana, N. 2006) . The methods used to build critical thinking in the lesson plan are:

1. Asking not only what happened, but also "how" and "why" it happened.

2. Examine the facts that are considered correct to determine whether it is proven to support new ideas.

3. Arguing in a logical way rather than using emotion.

4. Recognizing that sometimes there are more than one answer or good explanation.

5. Comparing various answers to a question and assess which ones are truly the best answers.

6. Evaluating and better asking what other people say than immediately accept it as the truth.

7. Asking questions and creating further speculations widely known to create new ideas and new information.

One way to encourage the students to think critically is giving them problems in real life that present two sides of the problem for discussion. Critical thinking is enhanced when students encounter arguments and debates in conflict, which can motivate them to solve a problem. 
IJEMS: Indonesian Journal of Education and Mathematical Science

2020 Vol. $x$, No. $1, p p$.

$\operatorname{ISSN}(e): 2715-985 x$

DOI: https://doi.org/10.30596/ijems.v2i1.5626

(C)2020IJEMS@UMSU.All RightsReserved.

\section{METHODOLOGY}

Development research refers to development research methods (Sugiyono. 2008; Borg, W.R. and Gall, M.D. 2010) aimed at developing and producing learning tools in the form of valid and practical LKM, being tested and implemented in lecturing process. In PBL, students work in small collaborative groups and learn what they need to know in order to solve a problem while the teacher acts as a facilitator to guide student learning through the learning cycle (Hmelo-Silver, C.E. 2004). A solution may be reached, or the group may perceive that there is more than one solution, or they may be unable to reach a solution with the information that they have (Wood, E.J. 2004). The Internet self-efficacy scores of participants were therefore measured at the beginning of the present study to establish if this factor might affect their learning outcomes after the intervention (Baturay, M.H and Bay, O.F. 2010). In conducting the problem-based learning, the strategy should be defined first to improve each problem stated in the research question by identifying indicators to evaluate the strategies applied, then data collection and analysis have been done to evaluate the results obtained in each indicator, and consequently to assure that the strategies have been implemented in the proper manner (Pons, et.al. 2015). The procedures for developing LKM of Mathematics statistics based on the problems are as follows:

1. Define Stage or Preliminary Stage

The preliminary study phase in this study begins by observing the students to find out their condition, teaching and learning activities, and teaching materials used in lecturing. Learning achievement as well as the objectives are developed in required teaching materials referring to the Higher Education SN curriculum.

2. Design Stage

The design phase is conducted by designing a problem-based Mathematical Statistics LKM. It is based on the problems that have been analyzed at the stage of defining, so that the developed LKM is a problem-based Mathematics Statistics LKM designed to overcome all existing problems.

3. Development Stage

The development stage in this study is started by conducting an LKM test of problem-based mathematics statistics consisting of readability and feasibility tests. The feasibility test is the content, presentation, and linguistic feasibility carried out by colleagues in the mathematics education program as validators aiming to determine the feasibility level of the Mathematics Statistics LKM based on syllabus and RPS problems. Besides, the assessment is also given by students who aim to look at the content as a whole. After obtaining data from a small-scale test, then analyze, evaluate and make improvements. After making improvements, a problem-based Mathematics Statistics LKM is obtained to improve the students' critical thinking skills.

4. Disseminate Stage

The next stage is a large-scale test. It is conducted by testing problem-based Mathematical Statistics LKM for 45 students and using it as one of the learning resources in learning Mathematics Statistics. The next step is to do a large-scale analysis on the critical thinking abilities of students in the learning process using the problem-based Mathematical Statistics LKM, so that based on the results after the analysis is done the problem will be obtained.

The obtained Data are in the form of qualitative and quantitative data. In this study, qualitative and quantitative descriptive analysis techniques were applied. Qualitative descriptive based on data scores from the validation of material experts in Mathematics Statistics, individual tests, expert development of LKM Mathematical Statistics of PBL models, and field tests. Percentage technique is applied to present data in the form of frequency to the response of the test subjects to the LKM Mathematics Statistics product based on the problem by using the formula (Lestari, N. et.al. 2014):

$$
P=\frac{\Sigma X_{i}}{\Sigma X} \times 100 \%
$$

$\mathrm{P}=$ percentage

$\sum \mathrm{X}_{\mathrm{i}}=$ sum of total score from validator

$\sum \mathrm{X}=$ sum of ideal score

In giving meaning and decision making to revise the LKM, the Mathematics Statistics based on the problems will use qualifications of the following criteria (Lestari, N. et.al. 2014).

\begin{tabular}{lll}
\hline Percentage & Qualification & Criteria \\
\hline $89<$ skor $\leq 100$ & Excellent & No revision \\
\hline $74<$ skor $\leq 89$ & Good & No revision \\
\hline $64<$ skor $\leq 74$ & Medium & Need rivision \\
\hline $54<$ skor $\leq 64$ & Bad & Revision \\
\hline $0<$ skor $\leq 54$ & poor & Revision \\
\hline
\end{tabular}

To find out the improvement in critical thinking skills before being given treatment (pretest) and after being given treatment (posttest) a gain test is used. The increase in pretest and posttest can be calculated by the following equation (Savinainen \& Scott. 2002). 
IJEMS: Indonesian Journal of Education and Mathematical Science

2020 Vol. $x$, No. $1, p p$.

$\operatorname{ISSN}(e): 2715-985 x$

DOI: https://doi.org/10.30596/ijems.v2i1.5626

(C)2020IJEMS@UMSU.All Rights Reserved.

$$
g=\frac{S_{p o s t}-S_{p r e}}{100-S_{p r e}}
$$

$\mathrm{g}=$ gain factor

$\mathrm{S}_{\text {pre }}=$ average score of pre test $(\%)$

$\mathrm{S}_{\mathrm{post}}=$ average score of posttest $(\%)$

Criteria of gain factor:

\begin{tabular}{ll}
\hline Gain Factor & Criteria \\
\hline $0<\mathrm{g}<0,3$ & Low \\
\hline $0,3 \leq \mathrm{g} \leq 0,7$ & Medium \\
\hline $0,7<\mathrm{g} \leq 1$ & High \\
\hline
\end{tabular}

\section{RESULT AND DISCUSSION}

From the results of the study, the developed product is a problem-based Mathematics Statistics LKM. Problembased Mathematical Statistics LKM is prepared by using learning achievement (CP) that is the students are able to use the concepts of probability; distinguish discrete random variables, continuous random variables, and exponential family distributions; differentiate the properties of expectation values, conditional expectations, and the function of the moment generator; differentiate the properties of expectation values, conditional expectations, and moment generating functions, and explain the transformation of random variables by using distribution function techniques, transformation methods, convolution formulas, and moment generating functions. Problem-based learning chosen in the preparation of an LKM can improve the ability to think critically by practicing problem solving skills in the form of current discourse. The applied LKM is divided into several learning activities according to the syntax that is in the learning with the PBL model. The LKM is in the form of print media, and consists of titles, learning achievement, and activities and exercises that must be completed. The characteristics of the compiled Mathematics Statistics LKM are:

1. Mathematical Statistics LKM is compiled systematically according to the character of students based on problembased learning.

2. List and explain learning achievement so that they can guide students in carrying out activities.

3. Mathematical Statistics LKM is prepared by giving exercises in it so that students can solve the problem independently or in groups.

TABEL (1). Scoring Mathematics Statistics LKM by Colleagues

\begin{tabular}{lccccccc}
\hline \multirow{2}{*}{ Learning materials } & \multicolumn{3}{c}{ Score } & \multirow{2}{*}{ Sum } & Average & Percentage & Category \\
\cline { 2 - 4 } & V1 & V1 & V2 & & & & \\
\hline Syllabus & 45 & 43 & 40 & 128 & 42,67 & 77,58 & Good \\
RPS & 50 & 49 & 52 & 151 & 50,33 & 91,52 & Excellent \\
LKM & 52 & 55 & 53 & 160 & 53,33 & 96,97 & Excellent \\
\hline
\end{tabular}

From the results of the study, it was obtained the results of the assessment by Student Worksheet (LKM) on Mathematics Statistics based on PBL by expert validators. The LKM assessment by colleagues for the syllabus assessment it was obtained $77.58 \%$ in good category, this states that the syllabus is good but needs to be improved especially the scope of the materials. While the evaluation of the RPS obtained a percentage of $91.52 \%$ in the very good category, however, there must still be improvements especially the achievement of learning and the material presented. While the assessment of the LKM obtained a percentage of $96.97 \%$ with a very good category. However, the MFI also experienced improvements in the use of language, material that must be adjusted to the learning achievements. The average percentage of 3 assessors obtained $88.69 \%$ with good categories, so that it can be concluded that the LKM of problem-based mathematical statistics does not need to be revised. 
IJEMS: Indonesian Journal of Education and Mathematical Science

2020 Vol. $x$, No. $1, p p$.

$\operatorname{ISSN}(e): 2715-985 x$

DOI: https://doi.org/10.30596/ijems.v2i1.5626

(C)2020IJEMS@UMSU.All Rights Reserved.

TABEL (2).The Students' response towards LKM

\begin{tabular}{lll}
\hline Aspects & Percentage & Category \\
\hline Qualification of the whole LKM & 84,56 & Excellent \\
\hline Qualification of material presentation & 90,32 & Excellent \\
\hline Content & 87,40 & Good \\
\hline Space for the exercise & 75,65 & Good \\
\hline Qualification of model & 74,35 & Good \\
\hline Qualification of the ability to think critically & 75,25 & Good \\
\hline
\end{tabular}

From table 2 of the responses of students to MFIs Mathematical statistics based on the problem is said to be good or average the percentage is $81.26 \%$ with good category (no need to be revised). So that there is no need to revise the Mathematics Statistics LKM. Description of critical thinking skills and description of students' cognitive abilities based on pretest and posttest scores after attending the mathematics statistics course using the MFI Mathematical statistics based on problems are presented in Table 3 below.

TABEL (3). Result of Pretest dan Posttest

\begin{tabular}{llllll}
\hline Test & Sum & Min & Max & Average & Deviation Std. \\
\hline Pretest & 45 & 50 & 75 & 62,98 & 7,19 \\
Posttest & 45 & 65 & 90 & 77,76 & 7,12 \\
\hline
\end{tabular}

From the results of the pretest and posttest, Gain and N-gain were obtained to show the difference / increase from pretest to posttest. Table 4 shows the description of data gain and N-gain based on the pretest and posttest scores after learning by using Problem-Based Mathematical Statistics MFIs.

TABEL (4). Result of Data Gain and N-Gain

\begin{tabular}{llllll}
\hline Data & N & Min & Max & Average & Devitsion Std \\
\hline Gain & 45 & -7 & 36 & 14,17 & 9,31 \\
N-Gain & 45 & $-0,25$ & 0,75 & 0,38 & 0,23 \\
\hline
\end{tabular}

Based on Table 4 it can be seen that the normalized gain and gain data ( $\mathrm{N}$-gain) of 45 students, that can be used to determine the improvement of students' critical thinking skills after learning by using problem-based Mathematical Statistics LKM. It was concluded that there was a significant difference in scores on the pretest and posttest of critical thinking test results. This shows that the problem-based Mathematical Statistics LKM effectively improve students' critical thinking skills. This is in line with research (Irvan, et.al. 2015; Lestari, N. et.al. 2014) which states that LKM can improve students' creative thinking skills in learning. Social community is believed to be relatively poorly experienced within distance learning environments due to learners' disconnection (Baturay, M.H and Bay, O.F. 2010).

\section{CONCLUSION}

Qualifications of LKM Problem-based mathematical statistics are categorized as "Good" after field test. Effective problem-based Mathematical Statistics MFIs improve students' critical thinking skills, viewed from the ability of students to solve problems, to develop their own concepts in the learning process. Improvement in critical thinking skills and student learning achievement are significant but in the "medium" category after the Mathematics Statisticsbased MFI problem had been applied.

\section{REFERENCES}

Arends, L.R. (2008). Learning To Teach, Belajar untuk mengajar. Yogyakarta: Pustaka Pelajar.

Borg, W.R. and Gall, M.D. (2010). Applying Educational Research. New York. Longman.

Tanjung,Dian F; Edi Syaputra dan Irvan. (2020). Problem Based Learning, Discovery Learning, and Open Ended

Models: An experiment On Mathematical Problem Solving Ability. JTAM (Jurnal Teori dan Aplikasi Matematika). Vol. 4, No. 1, April 2020, pp. 9-16.

Hmelo-Silver, C.E. (2004). Problem-Based Learning: What and How do Students Learn? Educational Psychology Review, vol. 16, no. 3, September 2004.

Irvan, F Nurdiansyah and M Hayati. (2015). Pengembangan Lembar Kerja Mahasiswa pada Materi Fungsi Distribusi dengan menggunakan model Desain Dick and Carey pada program studi Pendidikan Matematika FKIP UMSU. Proseing Seminar Nasional Matematika dan Terapan 2015, jilid 1, pp. 187-194.

Lestari, N. Suciati and Sugiyarto. (2014). Pengembangan LKM Model PBL berbasis Potensi Lokal pada Mata Kuliah Bioteknologi untuk Meningkatkan Kemampuan Berpikir Kritis Mahasiswa di Universitas Muhammadiyah Kupang. Jurnal BIOEDUKASI vol. 7, no. 2, pp. 18-22. August 2014. 
IJEMS: Indonesian Journal of Education and Mathematical Science

2020 Vol. $x$, No. $1, p p$

$\operatorname{ISSN}(e): 2715-985 x$

DOI: https://doi.org/10.30596/ijems.v2i1.5626

(C)2020IJEMS@UMSU.All Rights Reserved.

Pons-Valladares, O., Gonzalez-Barroso, J.M., Lopez-Olivares, R. and Arias, I. (2015). Educational Project to Improve Problem-Based Learning in Architectural Construction Courses using Active and Co-operative Techniques. Journal of Construction, vol. 14(2), August, 2015.

Oktaviani, D.N. and Rokhman, M.S. (2014). Pengembangan Modul Statistika I Berbasis Konstruktivisme pada Pendidikan Matematika Universitas Pancasakti Tegal. Jurnal Penelitian dan Wacana Pendidikan vol. 8, no. 13. November 2014

Mairing, J.P. and Dadang, L. (2013). Pengembangan Lembar Kerja Mahasiswa Berbasis Masalah Dan Proyek pada Mata Kuliah Analisis Data. Jurnal Pendidikan, vol. 14, No. 2, September 2013, 53-61.

Mushlihuddin R, Nurafifah and Irvan. (2018). The effectiveness of problem-based learning on students' problem solving ability in vector analysis course. IOP Conf. Series: Journal of Physics: Conf. Series 948(2018) 012028

Mushlihuddin R, Sri Wahyun and Irvan. (2018). The Influence of the PBL Model to Improve the Student's Mathematical Ability of Reasoning and Proof. Proceeding of The First AD INTERCOMME 2018. Jilid 1, pp. 4651

Mushlihuddin R dan Irvan. (2017). The Influence of Activity, Creativity, Motivation on the Problem-Based Learning at FKIP-UMSU. JPMIPA Universitas Muslim Nusantara Al-Washliyah, vol. 2, No. 1, Juli 2017, pp. 93-98.

Sudjana, N. (2006). Penilaian Hasil Proses Belajar Mengajar.Bandung: PT Remaja Rosdakarya.

Sugiyono. (2008). Metode Penelitian Pendidikan, Pendekatan Kualitatif dan kuantitatif dan R \& D. Bandung. Alfabeta. 